\title{
A new record of Soosia diodonta (Férussac, 1821) (Gastropoda: Pulmonata: Helicodontidae) in Bulgaria
}

\author{
Dilian GeORGIEV ${ }^{1} \&$ SLAVEya StoyChEVA ${ }^{2}$ \\ ${ }^{1}$ Department of Ecology and Environmental Conservation, University of Plovdiv, Tzar Assen Str. 24, BG-4000 Plovdiv, Bulgaria, e-mail: \\ diliangeorgiev@abv.bg \\ ${ }^{2}$ NGO Green Balkans, Shesti Septemvri Str. 160, BG-4000, Plovdiv, Bulgaria, e-mail: slaveyastoycheva@abv.bg
}

\begin{abstract}
Georgiev D. \& Stoycheva S., 2007: A New Finding of Soosia diodonta (Férussac, 1821) (Gastropoda: Pulmonata: Helicodontidae) in Bulgaria. - Malacologica Bohemoslovaca, 6: 35-37. Online serial at $<$ http://mollusca.sav.sk $>20$ Nov-2007.

The second finding of the rare south-east European endemic land snail Soosia diodonta (Férussac, 1821) in Bulgaria was reported. The locality was situated in Eastern Stara Planina Mts., west from Kotel town, near the road to Zeleniche Forestry and the Kotlenska River, before Prikazna Cave, UTM: MH 55. Soosia diodonta was found in beech (Fagus sylvatica) forest on a limestone terrain near a river. It was the most eastern ever known locality of this species.
\end{abstract}

Key words: Soosia diodonta, new locality, Bulgaria

\section{Introduction}

The land snail species Soosia diodonta (Férussac, 1821) (Gastropoda: Pulmonata: Helicodontidae) is a south-east European endemic species which occurs in the Eastern Serbia, Western Romania and Bulgaria (DAMJANOV \& LIKHAREV 1975). The only known locality of this species in Bulgaria was near the Boyanski waterfall in Vitosha Mts. (URBAŃSKI 1964), but its occurrence in the country remained uncertain (DEDOV 1998).

\section{Material and methods}

Two trips in Eastern Stara Planina Mts. for gathering malacological materials were made in June 2003 and September 2007. The material was collected by hand and using a sieve for the soil samples (DAMJANOV \& LIKHAREV 1975). The land snail species names used in the paper are after HUBENOV (2005).

\section{Results}

Locality of Soosia diodonta: Eastern Stara Planina Mts., west from Kotel Town, near the road to Zeleniche Forestry and the Kotlenska River, before Prikazna Cave, UTM: MH $55,42^{\circ} 53^{\prime} \mathrm{N}, 26^{\circ} 24^{\prime} \mathrm{E}, 600 \mathrm{~m}$ a.s.l. (Fig. 1). This locality is the most eastern known one for this species.

Material: (1) Jun 2003 (the exact date not known) - two live individuals, under a dead tree trunk, these specimens were not killed and were released back in the nature; (2) 13 Sep 2007 - one shell in a Fagus sylvatica tree leaf detritus, dimensions: shell height $4.8 \mathrm{~mm}$, shell width $10.9 \mathrm{~mm}$ (Fig. 2). The shell collected on 13 Sep 2007 was deposited in the collection of the first author.

Habitat: A beech (Fagus sylvatica) forest on a limestone terrain near a river.

For other land malacofauna in the same UTM-grid square see Table 1. 


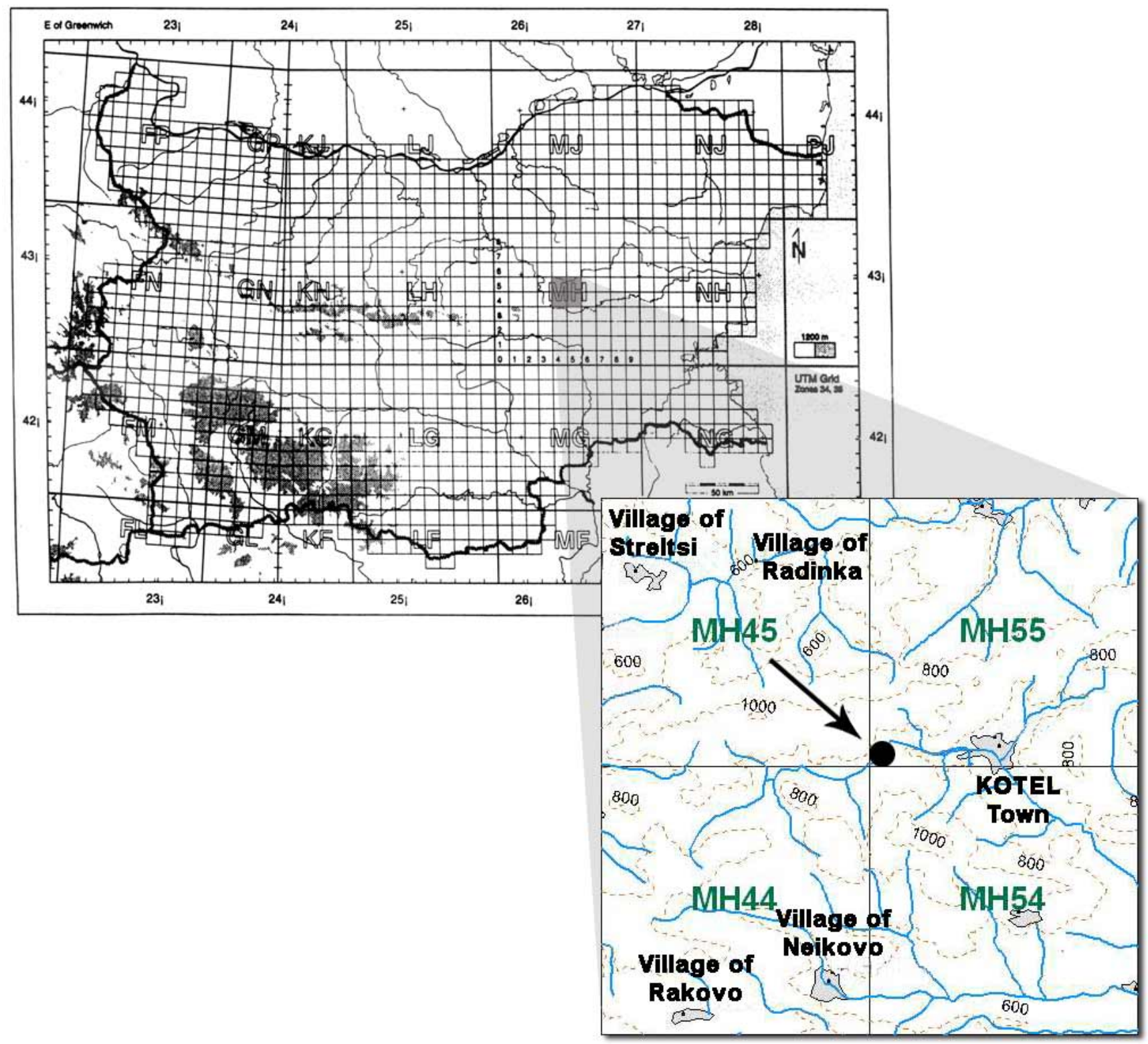

Fig. 1. The new locality of finding the Soosia diodonta (Férussac, 1821) in Bulgaria.

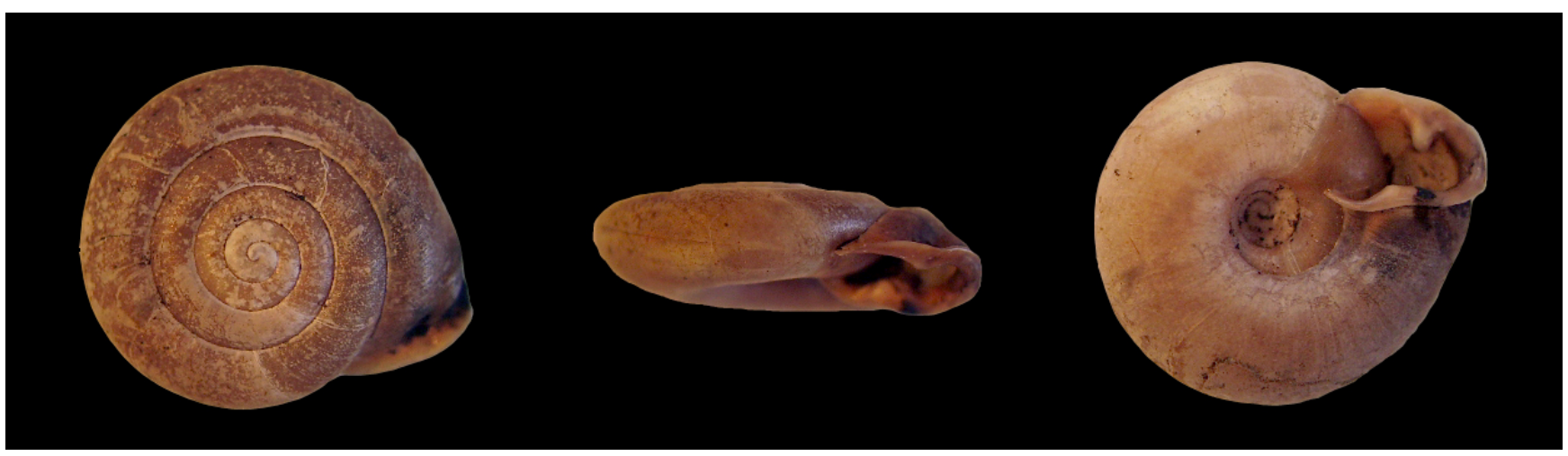

Fig. 2. Shell of the specimen of Soosia diodonta (Férussac, 1821) found on 13 Sep 2007. 
Table 1. Land malacofauna of the UTM locality of finding of Soosia diodonta (Ferussac, 1821). Remark: The species O. glaber was also found living in the caves (Drianovskata Peshtera Cave).

\begin{tabular}{|c|c|c|c|}
\hline \multirow[t]{2}{*}{ species } & \multicolumn{3}{|c|}{ habitat } \\
\hline & Farus sylvatica forest & Carpinus orientalis forest & Grassland \\
\hline Pomatias rivulare (Eichwald, 1829) & $*$ & $*$ & $*$ \\
\hline Carychium tridentatum (Risso, 1826) & $*$ & & \\
\hline Chondrina avenacea (Bruguiere, 1729) & $*$ & & \\
\hline Merdigera obscura (O.F. Müller, 1774) & * & & \\
\hline Zebrina detrita (O.F. Müller, 1774) & & $*$ & $*$ \\
\hline Cochlodina laminata (Montagu, 1803) & $*$ & & \\
\hline Macedonica marginata (Rossmässler, 1835) & $*$ & & \\
\hline Mentissela rebeli (Sturany, 1897) & $*$ & & \\
\hline Laciniaria plicata (Draparnaud, 1801) & $*$ & & \\
\hline Balea biplicata (Montagu, 1803) & * & & \\
\hline Arion silvaticus Lohmander, 1937 & $*$ & & $*$ \\
\hline Euconulus fulvus (O.F. Müller, 1774) & $*$ & & \\
\hline Vitrea diaphana (Studer, 1820) & $*$ & & \\
\hline Aegopinella pura (Alder, 1830) & $*$ & & \\
\hline Aegopinella minor (Stabile, 1864) & $*$ & & \\
\hline Oxychilus investigatus Riedel, 1993 & $*$ & & $*$ \\
\hline Oxychilus glaber (Rossmässler, 1835) & $*$ & & \\
\hline Oxychilus inopinatus (Uličný, 1887) & $*$ & & \\
\hline Daudebardia rufa (Draparnaud, 1805) & $*$ & & \\
\hline Tandonia kusceri (H. Wagner, 1931) & & & $*$ \\
\hline Tandonia cristata (Kaleniczenko, 1851) & $*$ & & \\
\hline Limax maximus Linnaeus, 1758 & * & & \\
\hline Deroceras sturanyi (Simroth, 1894) & $*$ & & $*$ \\
\hline Helicigona trizona (Rossmassler, 1835) & $*$ & $*$ & $*$ \\
\hline Cepaea vindobonensis (Ferussac, 1821) & & $*$ & $*$ \\
\hline Helix lucorum Linnaeus, 1757 & $*$ & & \\
\hline Bradybaena fruticum (O.F. Müller, 1774) & & & $*$ \\
\hline Soosia diodonta (Ferussac, 1821) & $*$ & & \\
\hline Linholmiola girva (Friveldszcky, 1835) & $*$ & & \\
\hline Trichia erjaveci Brusina, 1870 & * & & \\
\hline Xerolenta obvia (Menke, 1828) & & $*$ & \\
\hline Monachoides incarnatus (O.F. Müller, 1774) & $*$ & & \\
\hline Monacha cf. carascaliodes (Bourguignat, 1855) & & $*$ & \\
\hline Monacha sp. & $*$ & & \\
\hline Euomphalia strigella (Draparnaud, 1801) & & & $*$ \\
\hline
\end{tabular}

\section{References}

DAMJANOV S. \& LiKHAREV I., 1975: Fauna Bulgarica, 5. Terrestrial snails (Gastropoda terrestria). - Marin Drinov Publ., Sofia, 425 pp. (in Bulgarian).

DEDOV I., 1998: Annotated check-list of the Bulgarian terrestrial snails (Mollusca, Gastropoda). - Linzer Biol. Beitr., 30 (2): 745 765 .
HUBENOV Z., 2005: Malacofaunistic diversity of Bulgaria. - In: Current state of Bulgarian biodiversity - problems and perspectives , Petrova A. (ed.) Bulgarian Bioplatform, Sofia, 199-246 (in Bulgarian).

URBAŃSKI J., 1964: Beiträge zur Kenntnis balkanischer Stylommatophoren (Systematische, zoogeographiche und ökologische Studien über die Mollusken der Balkan-Halbinsel. VII.). - Bull. Soc. amis Sci.et Lettr., Poznań, ser. D, 4: 19-56. 